Journal of Social Sciences (COES\&RJ-JSS)

ISSN (E): 2305-9249 ISSN (P): 2305-9494

Publisher: Centre of Excellence for Scientific \& Research Journalism, COES\&RJ LLC

Online Publication Date: $1^{\text {st }}$ January 2017

Online Issue: Volume 6, Number 1, January 2017

https://doi.org/10.25255/jss.2017.6.1.1.13

\title{
Empirical model pupil management integrating with balancing competitive-solidarity value for the preparation of character generation competitive and social- solidarity to be ready demographic bonus and the best economic era
}

\author{
Ali Imron \\ Universitas Negeri Malang \\ Professor in Education Management of the State University of Malang, \\ East Java, Indonesia
}

\begin{abstract}
:
This study was aimed at developing an empirical model of pupil management by integrating the balancing competitive-generation solidarity values to the preparation of competitive character and social solidarity values for enrolling in the era of demographic bonus and the best economy. At the first year, this study employed mixed method. At the second year, this study employed Research and development (R \& D) method.At the third year this study employed expose-facto and causal comparative methods. There were three main different school chategories being studied, which were good metropolitant high schools in Surabaya and Sidoarjo, East Java, medium suburbant schools in Pasuruan, East Java, and periphery suburbant schools in Malang and Blitar, East Java. The data were collected using closed and open questionnaires. The data were analized using descriptive statistics of central tendency and content analysis (content) of Mayring (2000). The quantitative data of discrepancies were analized using cross-tabs and the mean difference test techniques. The qualitative data of differences were analized using constant comparative technique (Bogdan, 1985; and Yin, 1995). This study resulted a conceptual model covering the model expert judgments and empirical models of pupil management that integrated competitive values, the values of solidarity, and both balancing values; pupil management activities and strategies conducive to integration of balancing competitive and solidarity values. The models have been applicable to be used to prepare the next generation competitive character and social solidarity in order to enroll in an era of demographic bonus and the best economy.
\end{abstract}

\section{Keywords:}

Management learners, Ccompetitive value, Ssolidarity value, demographic bonus, The best economy.

\section{Citation:}

Imron, Ali (2017); Empirical model pupil management integrating with balancing competitive-solidarity value for the preparation of character generation competitive and social- solidarity to be ready demographic bonus and the best economic era; Journal of Social Sciences (COES\&RJ-JSS), Vol.6, No.1, pp: 1-13; https://doi.org/10.25255/jss.2017.6.1.1.13. 


\section{INTRODUCTION}

Indonesia is to face the best opportunity era, which is the demographic bonus in 20202030 and at the same progress will be the best economy in the world by 2030. This era requires human beings who have the competitive advantage to compete in the global arena. At the same time, they are required to have a social solidarity that high society commit in uplifting the nation towards progress and prosperity. Educational institutions, including schools, have strategic positions on setting-up HR competitive character and social solidarity. Therefore, propper management is required for learners being transplanted the competitive-value solidarity to prepare the nation generation to be able to enroll in the era of demographic dividend and economic progress. Demographic dividend occurs when the amount of productive population (15-64 years) are larger (about 70\%) than the number of young people under 15 years old) and elderly (65 years and above) or unproductive population (approximately 30\%). In years 2020 to 2030 (as published by www.apindo.or.id), Indonesia will have about 180 million people of productive age and unproductive age of about 60 million inhabitants. The Pyramid structure that is "bulging in the middle" is advantageous, because the dependency ratio (dependency ratio) or economic support to be provided by the productive age population to the aged children population (under 15 years) and older (over 64 years) to be lighter. The Provisions of 10 people of productive age bear only 3-4 unproductive age people. This will have implications on improvement of people's savings and national savings (Alimoeso, 2013). Demographic dividend, which is the "golden age" of it, could be a potential when it can be managed optimally. Instead, it will turn into a threat to the state and nation economics, because of the impact it could cause social unrest to begin in the poverty rate and the number of unemployed people being increased. The "Opportunity once a century" offers an alternative called "Now or Never", because it the strategic measures and operation are not taken today, this will turn into a burden and even boomerang. Therefore, the setup requires quality human resources through education. As afforementioned concerning the demographic devident showed that the highest demographic bonus dependency ranges between $40-50 \%$, which means that 100 people aged $40-50$ bear the productive age. Professor of Demographics at Indonesian University, Prof. Dr Sri Moertiningsih Adioetomo, indicated that Indonesia already got the demographic bonus starting from 2010 and reached a peak in 2020-2030. As being said above, The Pyramid structure that is "bulging in the middle" is advantageous, because the dependency ratio (dependency ratio) or economic support to be provided by the productive age population to the children aged population (under 15 years) and older (over 64 years) to be lighter. This can be said that 10 people of productive age bear only 3-4 productive age people. This will have implications on improvement of people's savings and national savings. On the other hand, Indonesia has increased the productive age, accompanied by an increase in revenue. In 2003 to 2010, there has been a rise in per capita expenditure of Indonesia's middle class of $18.8 \%$. This indicates the increasing income of the people, along with the increasing number of middle class (Aviliani, 2011). Table 2.1 specifies the increase of the middle class in Indonesia which is likely to increase. Unfortunately, the amid optimism of demographics concerns that Indonesia still face with the problem of competitiveness, as reflected in the Human Development Index (HDI). HDI is a comparative measure of life expectancy, literacy, education and standard of living of all countries around the world. Based on the calculation of the United Nations Development Program (UNDP), Indonesia's HDI score is still lagging behind when compared with the Philippines, Thailand, Malaysia, Brunei Darussalam and Singapore. Thus, based on the severity of this nation's competitiveness compared with other countries, it is necessary to increase the 
competitiveness characters through educational activities. With ccompetitiveness characters, it is expected that the Indonesian generation are able to enroll in the demographic bonus and the best economy era. In addition, human social solidarity is also highly needed. The characters of social solidarity enable Indonesian people to posess empathy to their fellow citizens of the nation in preparing to enroll in the demographic bonus and the best economy era. The Ministery of Education of Indonesia Republic identified 18 grades of values in Education Culture and National Character sourced from religion, Pancasila (The Five Principles), culture, and national education goals. The Eighteenth values include religious, honest, tolerant, disciplined, hard working, creative, independent, democratic, curiosity, the spirit of nationalism, patrioticc, respect for the achievements, friendly/communicative, peace loving, reading loving, environmental caring, social caring, and responsible (Puskur, 2009). Researchers also gained the trust of Ministery of Education of the Indonesia Republics to arrange education guides of the characters development through extra-curricular activities (2011).

At the schooling unit level, the position of pupil management related to the preparation of future quality of human resources, including the demographic bonus era and the best economy is very strategic. Compared to other educational management substances (such as curriculum and learning, staff, infrastructure, financial and public participation), participant management educate swooping more directly to the formation of learners as desired (Yeager, 1985: Imron, 2011). Management of learners right from the recruitment of students, selection, orientation, early detection of potential, distribution, promotion (talents, interests), disciplining, to the release and even for sustainablele coaching until when they became the alumni (Indrakusuma, 1990; Gorton, 1991; Imron, 20011). Therefore, the pupil management is very strategic, when it becomes the container integrating positive values for students, including the value of competitiveness and solidarity (solidarity competitive-value) (Stoop \& Johnson, 1985).

Results of existing researches on the implementation of the management on quality primary (Imron, 2005; 2010) showed that students at top schools generally have high competitiveness characters and low social-solidarity. Learning is individualized and intensively done by competition, bringing nurturing effect (Joice, and Weil, 1980), the prominence of the individual nature and the nature of ego learners. While doing research on the implementation of SBM in junior high school at Nganjuk, Imron (2005) among others found no significant association between the implementation of school-based management students with academic and non academic quality of Yunior High School. Learners, who have high academic and non academic achievement, generally have low social-solidarities; the high solidarity students are generally being underachievement. Results of Imron's research on the SD-based religion, as published in the Journal of the National Accredited (Journal of Science Education) (2009) showed that there were sociocultural roots of SD-based religion, which inspired and encouraged the achievement of school quality. In SD-rooted socio-cultural urban cities, it was found out to have the rigor of competition among the school community, and had a lower level of solidarity. While the SD rooted socio-cultural locals was found to have high of "gotong royong" (Togetherness in helps), but low in the spirit of competition. The research recommended that there shall be intervention and habituation to balance the values of competition and solidarity in order that the school can reach the peak progress. In the 2013 curriculum, both he Education unit level and the curriculum also mandated to lead on the principle of balancing the values of competitive students and the values of 
solidarity (MONE, 1996; Kemendikbud, 2013). Learners are expected to compete up to the global scale; butt must have social solidarityies to other fellow learners and communities to their competitive advantage which will remain beneficial for the nation. However, up to the current situation, the integration of competitive values and social solidarities have not been done in the management of learners. These even have not been emphasized in the policy and management of the learners' school based management textbooks, as well as at the level of implementation in school education units. Therefore, there should be a first step to integrate these two values being balanced in the management of learners. These can be the support to all people to utilie the more welcomedemographic bonus and the best economy that will be experienced by Indonesia. Yeager (1985) and Knezevich (1981) define that the management of learners or pupil personnel administration as a service that is focused on the regulation, supervision and services in class and outside of class. The scope of management students in school are: recruitment, selection, orientation, identification of potential, grouping, distribution of talent and interest, coaching, increased discipline, the release, and even coaching after they graduate and become alumni of (Imron, 2011).

Character is basically the way of thinking and behaving that is the characteristic of each individual to live and work, both within the family, community, nation and state. Individuals who have good character are an individual who can make decisions and be ready to account for every result of a decision he made (Akbar, 2012). Character education is moral education plus, namely involving aspects of knowledge (cognitive), feeling (feeling), and action (action) (Lickona. 1992). Character education is a system that internalize character values to school-age children both related knowledge, the individual consciousness, determination, as well as their willingness and action to implement the values of good against Almighty God (Almighty), ourselves, our fellow human beings , with the environment, as well as to the nation (Kemendikbud, 2012). Strong competitive character is marked by a strong desire to be number one and with the strong reaction to the defeat. Some children, since their birth have brought competitive tendencies. Several features of the competitive nature are: (1) wanting to win them all and being difficult to accept defeat, (2) requiring acknowledgment of its success, (3) focussing on facts and not on the personal element, (4) having a task-oriented and targets, are less sensitive to relationships and feeling, (5) being stubborn and not easily give up or subject to people, (6) being capable and fast control field, (7) being impatient and critical, (8) requiring people like him, (9) being able to justify any means to get his wish, (10) have problems with the reception itself, or easily dropped in disappointment (Gunadi, 2013).

It is clear that the values of the existing competitiveness leading to positive attitudes, eventhough there also remains having negative aspects. Therefore, the positive competitiveness values are highly recommended to be integrated into the management of learners. Such values can include the followings: (1) having personality superior and devoted to strive for excellence, (2) being excited \& combative, (3) being independent, (4) being the unyielding, (5) being able for networking, (6) being friendly to change, (7) being innovative and becoming agents of change, (8) being productive, (9) having quality consciousness, (10) being globally oriented, (11) being learners throughout life, (12) taking as a mercy to the worlds (Gunadi, 2012 ). Solidarity can be interpreted as a unity of interests and their feelings of sympathy, and feel as one of the members of the class, and find themselves as having the same degree and position. Solidarity can be defined as a feeling or expression in a group formed by a common interest. Wikipedia 
(2012) gives a sense of solidarity as the level and type of integration, shown by people or groups of people and their neighbors. This refers to the relationship in society, such as social relationships and ties of solidarity. Solidarity also means the collective agreement and gain support, interests and responsibilities among individuals in the group, which is embodied in unanimous support and collective action to something.

If the competitive values are synergized with the solidarity values, these will reveal the following characteristics: (1) having the desire to win, but accepting to be defeated, (2) being delighted to receive the recognition of people, but can understand when people do not give him recognition, (3) having a balance between the nature of the objective and subjective in view of the facts and the personal element, (4) having the tendency to be oriented on the tasks and targets but sensitive by a factor of relationships and feelings, (5) remainning stubborn but can be subject to the other, (6) being skilled and control field, (7) having the limited patience and critical, but can control his emotions, (8) having the tendency to require people like himself but can understand the uniqueness of people, (9) being not to do anything to get what he wants, (10) accepting themselves and others with all its strengths and limitations, and (11) being dropped when disappointed but did not last long (http: //www.shovving.comkaraktermanusia indonesiaseutuhnya.html. 2012). Therefore, various recommendations regarding the management of learners that integrates competitive-solidarity values have been proposed as follo: (1) providing a vehicle for the distribution on the desire of children to actualize their capabilities, (2) setting the target slightly above its ability to increase thrust, (3) not emphasiing ratings on results, but on the business, (4) not praising the poor but do not also too spit praise, (5) doing comparisons with other children; always use himself as a benchmark, (6) often highlighting the character himself or others as the criteria we use to judge, (7) recieving failure appropriately, not underestimating or raising failure, (8) teaching to understand which is the distinct from it; telling the background or the situation facing people who made them like that, (9) educating to control anger and to express feelings in a healthy, for example, be angry, but do not insult; be angry but do not have to shout (http://id.answers.yahoo.com/question/ index, 2012).

The purpose of this study was to: (1) describe the feasibility of this model by integrating the management of learners to balance solidarity competitive-values, (2) develop a management model of learners by integrating the balancing competitive-solidarity values. The model is epected to be used in preparing generation having competitiveness character and social solidarity values to enroll in the era of demographic bonus and the best economy.

\section{RESEARCH METHODS}

At the first year (2014), this study employed a mixed method developed from Tashakkori and Teddlie (2003), by using the quantitative-qualitative sequential (the dominant method is quantitative, incorporating qualitative methods) design as proposed by Steckler et al. (1992) and Rose (2003). This study was continued by employing the Research and Development (RD) Borg and Gall (1992) complemented by Dick and Carey (1996). At the second year (2015), this study was continued using Research and Development (R \& D) method. This method was also adopted from Borg and Gall (1992) complemented by Dick and Carey (1996), as a continuation of the R \& D performed at the first year. At the third year (2016) this was followed by a descriptive-causal-comparative method, namely: 
(1) model desimination, (2) model implementation assistance, (3) descriptive-causal comparative analysis, (4) guidelines development, and (5) textbooks preparation ( Learners management by integrating the balancing competitive- solidarity values to enhance the competitive characters and social solidarity to face the era of the demographic bonus).

At the first year, this study aimed the 3 (Three) public high schools, vocational schools, and religious schools respectively in the East Java. The data were collected using closed and openned questionnaires to the identiy and eplore the competitive and solidarity values. This study also employed the Quantitative data analysis techniques using the descriptive statistical measure of the tendency centripetal (central tendency) (Sugiyono. 2005). Furthermore, this study also used the mecanical analysis of qualitative data using content analysis of Mayring (2000). Based on the results of these data analyses, it was found out variances as follow: (1) the competitive-solidarity value integrated in the management of learners, (2) the competitive value synergized with solidarity value, (3) the learners management activities framed into a container balancing competitive-solidarity values, and (4) the conceptual model of learners management in the integration of balancing competitive-solidarity

value.

At the second year, the data collection techniques in the development stage were as follow: (1) using closed and openned questionaires about the feasibility of integration model to balance the competitive-solidarity values in the management of learners by experts (2) closed and openned questionaires about the feasibility of integration model balancing competitive-solidarity value in the management of learners by implementer (vice principal of student affairs and student supervisors) to obtain empirical verification. Quantitative research data were analyzed using descriptive statistics centripetal tendency distribution frequency (Sugiyono. 2005) and using content analysis techniques of Mayring (2000).

At the third year, the data collection techniques in the dissemination, mentoring, writing guidelines and textbooks were using instruments feedback. The difference between the conceptual-theoretical models, expert judgment models, empirical models and the final model, and quantitative data were tested by cross-tab (cross tabulation) and different test mean. The diferent beteen the conceptual-theoretical models, expert judgment models, empirical models and final model were quantified and tested using a constant comparative analysis techniques (Bogdan, 1985 and Yin, 1995).

\section{RESEARCH RESULT}

Results of the research revealed the conceptual model, the results of expert testing, expert judgment models, empirical test results and models as well as empirical models. The folloing is the frameork of the empirical model integrating the management of learners in balancing competitive-solidarity value. 
Figure 1.Empirical Model Integration Competitive Value in Pupil Management

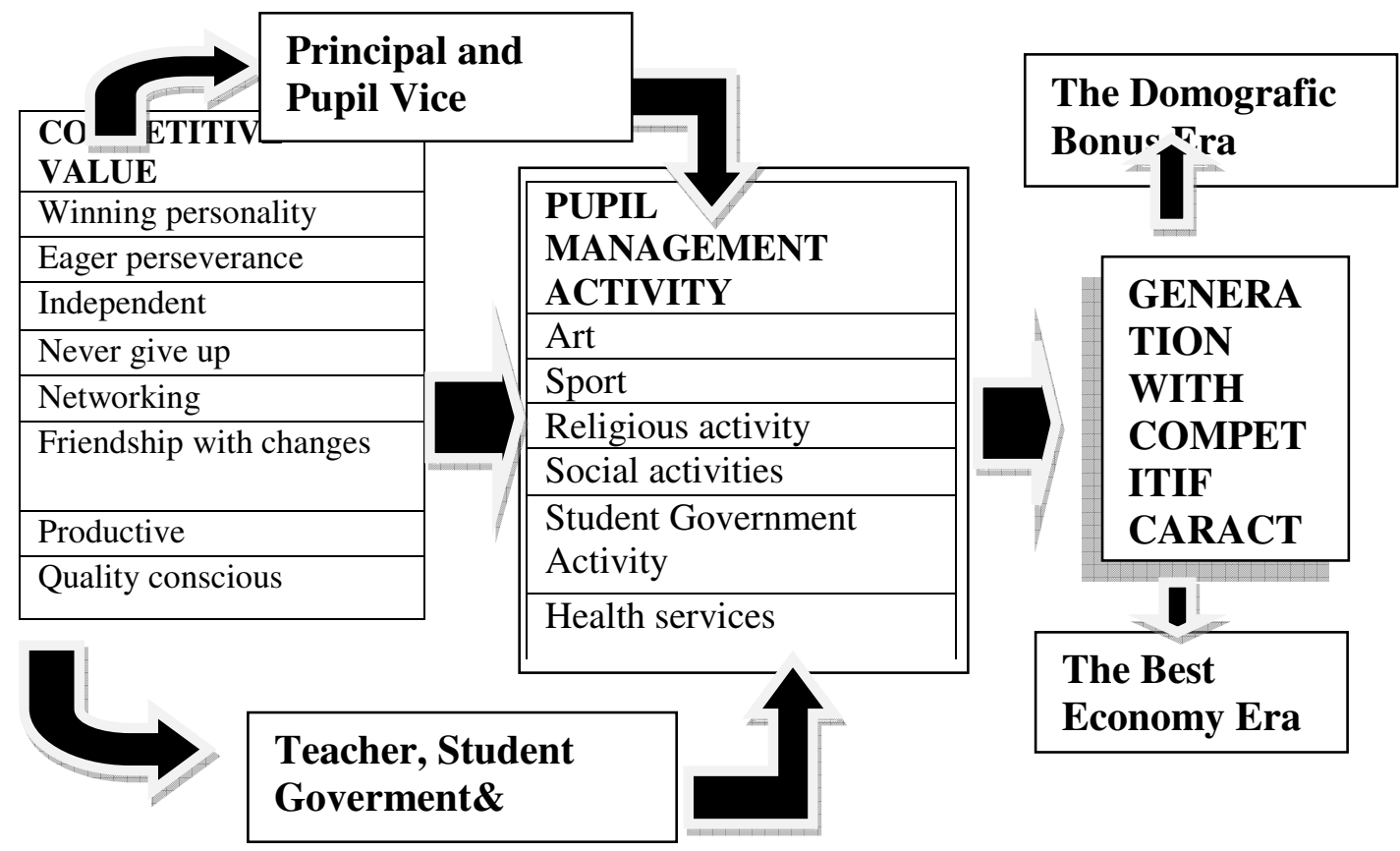

This model is consistent with the theory and systems approach, which provides an overview of input, process and output. As input values are competitive, while the process is the integration done by principals, vice-principals, teachers and students in management activity participants learners. While the output is the character of students competed in a competitive era and ready for the era of the demographic bonus and the best economy.

The folloing feagure shows the Model integration of the values of solidarity in the pupil management, subtantiating the solidarity value that can be integrated into the management activities of students, which includes: being friendly, tolerant, able to compromise, being eager for sharing, having social networking, being helpful, being eager for understanding, being empathy, being familiar, taking opportunities, and provide convenience. Meanhile, the learners own management activities consist of: arts, sports, religious activities, special talent development activities, social activities, skill of activities, student council activities, and health services. Integrating the value of solidarity is the principal, vice principal of student affairs, teachers, administrators and student council. The purpose of this integration has been to create social solidarity generation, so has great benefits for the citizens of the nation when the era of the demographic bonus and the best economy has come. The model can be framed as follow: 
Feagure 2.Model Integration Solidarity Values in Pupil Management

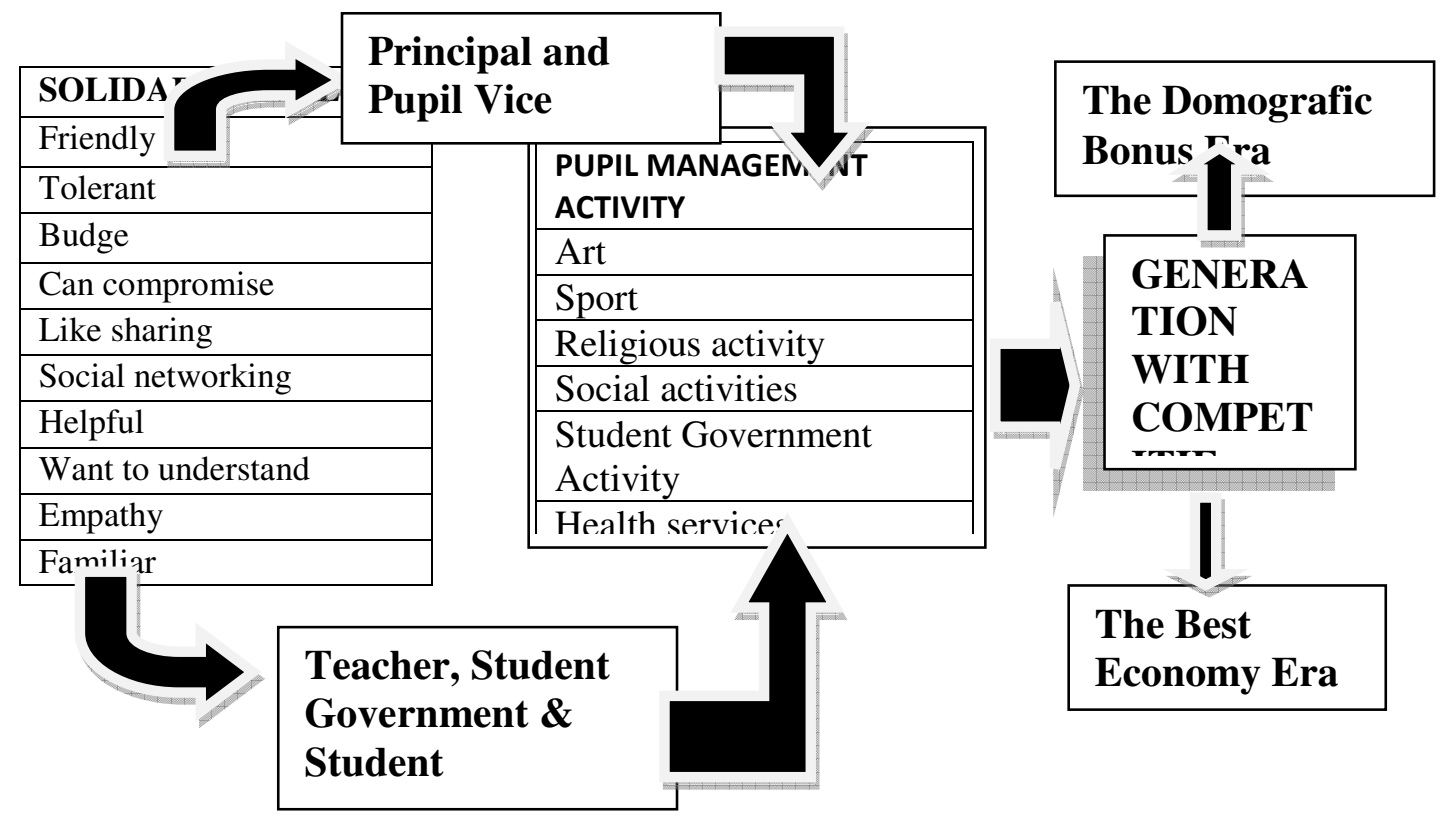

This model is also consistent with the theory and systems approach. As the inputs are the values of solidarity, while the process is the integration done by principals, viceprincipals, teachers and students in the management activities of learners. Meanile, the output is high social solidarity students and provide benefits to the citizens of the nation in the era of the demographic bonus and the best economy.

The next model to be reported is the Integration Model in Balancing Competitive and Solidarity Values in pupil management. Such model revealed the characteristics as follow: wanting to win, but could budge; being pleased to be recognized, but unwilling to admit; being balanced to look at the facts and the personal element; having task-oriented, but were sensitive to the relationship; stubborn, but may have been subjective; being skillful and mastering the art; critical, but being able to control the emotions; perceiving people like himself, but understood the uniqueness of people; striving for achieving the goals, but being not to justify any means; accepting themselves and others entirely. learners management Activities were found out similar to the two previous models as framed in the folloing feagure. 
Figure 3. Balancing Integration Model of Competitive Values and Solidarity in Pupil Management.

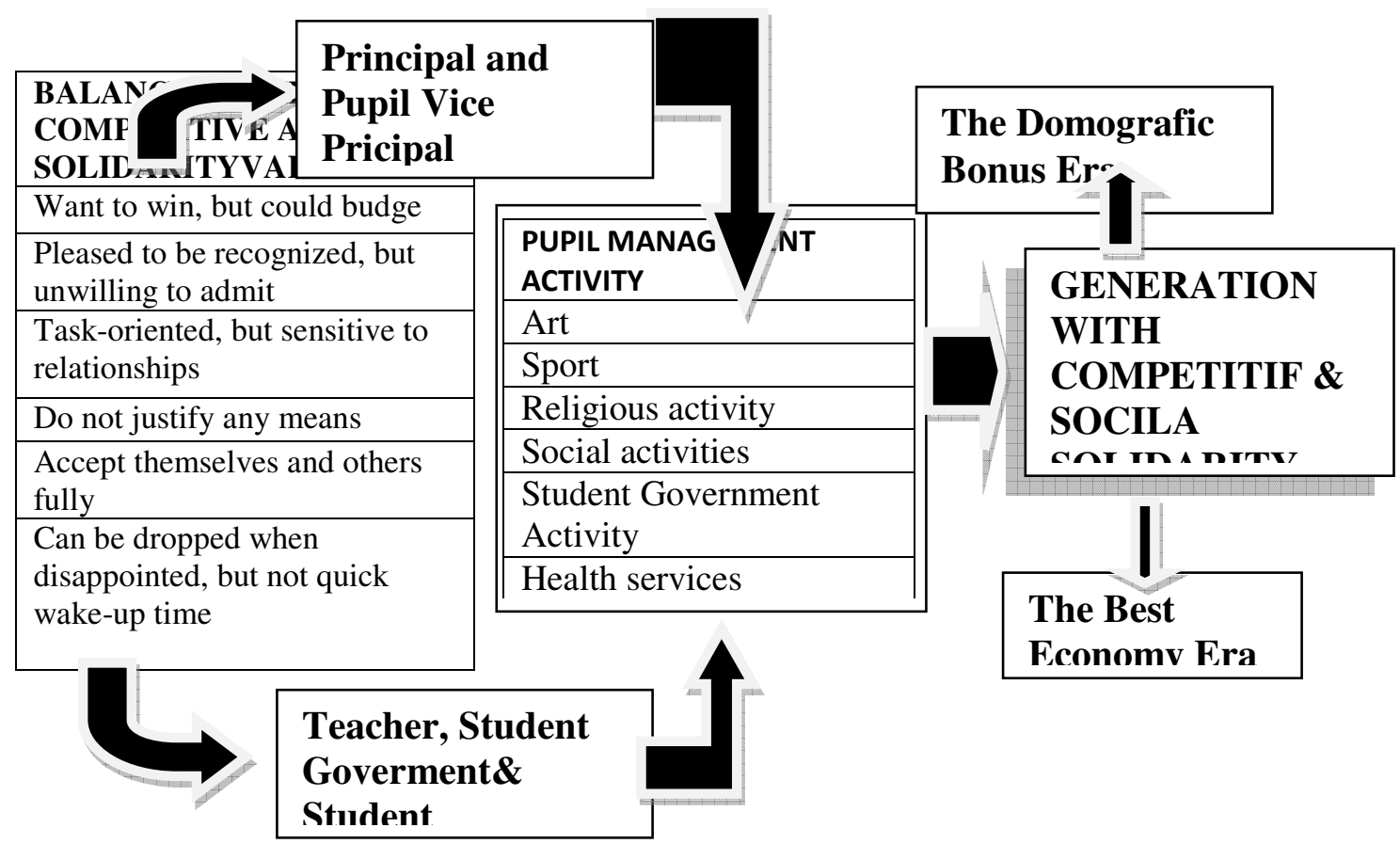

This model is also consistent with the theory and systems approach, which is the balancing values, while the process is the integration done by principals, vice-principals, teachers and students in the management activities of learners. Meanile, the output is the competitive values and students are characterized by high social solidarity to survive and members great benefits in an era of demographic bonus and the best economy.

The next model to be reported is Model of Strategies to Conducive Balancing Competitive-Solidarity Value to Pupil Management. This model characterized by: providing a vehicle for channelling the desire to actualization ability; having capability of slightly above the target set capability; having assessment focused on the business, not just the result; accepting failure, but did not underestimate and exaggerated failure; conditioning controlled anger. The pupil management activities were developed and implemented together with the three previous models. This model can be framed in the folloing feagure: 
Figure 4. Model of Strategies to Conducive Balancing Competitive-Solidarity Values to Pupil Management.

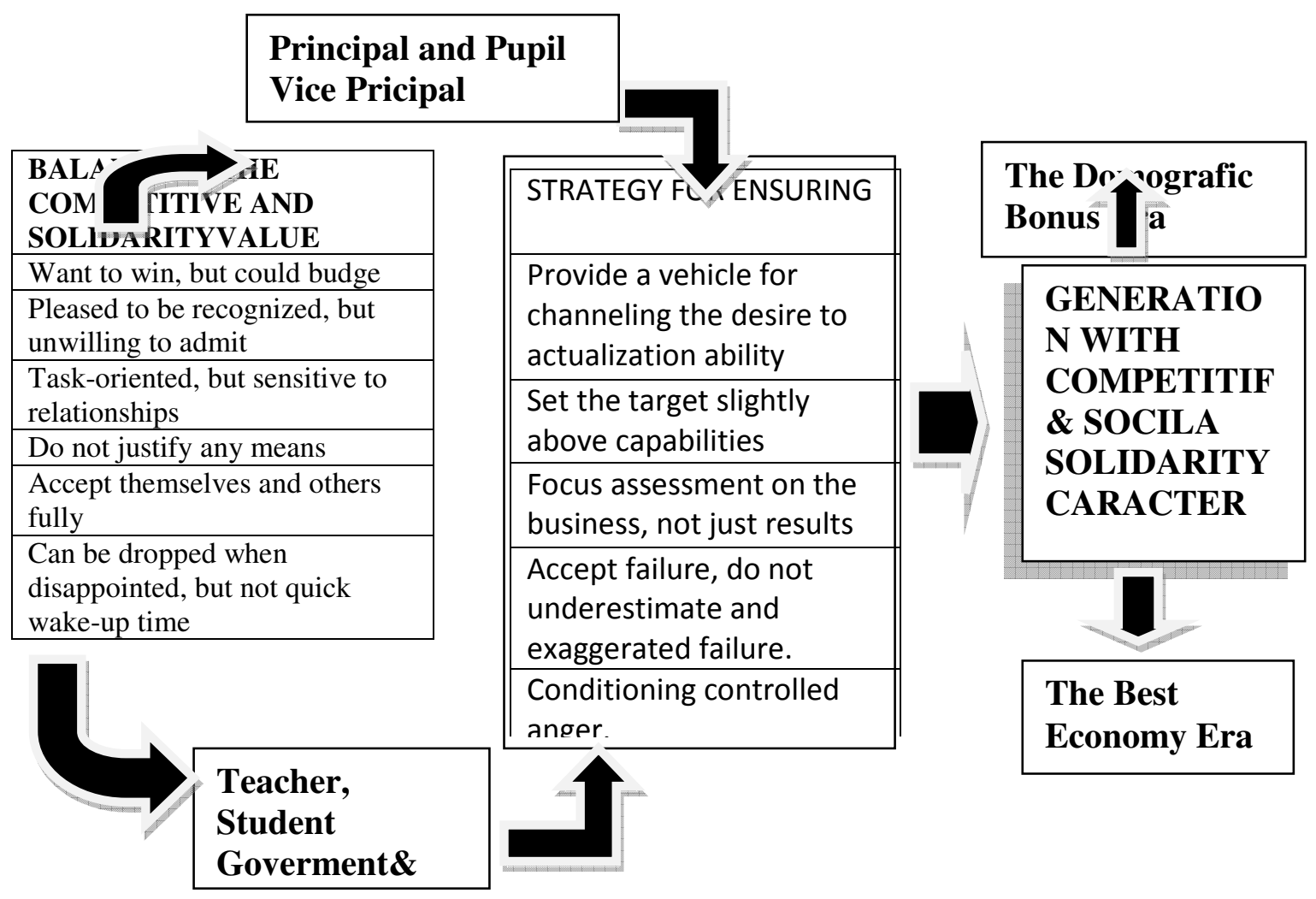

This model is also consistent with the theory and systems approach, which contain the conducive balancing strategy. The process of integration is done by the principals, viceprincipals, teachers and students in the Pupil Management. Meanwhile, the outputs are competitiveness values and students are characterized by high social solidarity to survive and bring substantial benefits to the citizens of the nation in the era of the demographic bonus and the best economy.

\section{CONCLUSIONS AND SUGGESTIONS}

This study concludes that firstly, at the first year, there were four conceptual models established as follows: (1) the integration model of competitive values in management activities of learners, (2) model of integration of the values of solidarity in the management activities of learners, (3) the integration model balancing competitive values and solidarity in the management of learners, and (4) model of conducive strategy of balancing competitive values and solidarity in the management of learners; secondly, at the second year, there were four models of expert judgment established as follows: (1) model of expert judgment in integration of competitive values in management activities of learners, (2) model of expert judgment in integration of the values of solidarity in the 
management activities of learners, (3) model of expert judgment in balancing the integration of competitive values and solidarity in the management of learners, and (4) model of conducive balancing strategy expert judgment in competitive values and solidarity in the management of learners; thirdly, the conceptual model produced at the first year, and those tested by the experts were empirically tested, thus producing an empirical model as follows: the empirical model of integration of competitive values in management activities of learners, (2) the empirical model of integration of the values of solidarity in management activities of learners, (3) the empirical model of integration of balancing competitive and solidarity values in the management of learners, and (4) the empirical model of conducive balancing strategy competitive values and solidarity in the management of learners.

It has been suggested that firsly, to the Ministry of Education and Culture of the Indonesia Republic to develop policies that specifically integrate competitiveness and solidarity values in a balanced frameork in the management of learners, as an integral part of the overall education management; secondly, the policy of the School Based Management (SBM), in which the substance of the management are learners, is to be focused on provisioning balanced competitiveness-solidarity values to enable learners to become the capabale generation to enroll in the era of demographic bonus and the best economy; thirdly, to the school principal, vice principal of student affairs and the Trustees of student activities to use the results of this study as a guide in integrating competitiveness and solidarity values. By integrating both values which are balanced, it is expected to spur the students to have a competitive advantage and high social solidarity; fourthly, the management model that integrates learners equitably competitiveness and solidarity values should be used as a reference by the developers of management science education in integrating various types of characters that are now recommended by the Ministry of Education and Culture of the Indonesia Republic; fifthly, the conceptual model, expert judgment and empirical generated by this study should be disseminated to schools, because these are ready for practical application.

\section{References}

Alimoesa, 2013.PertumbuhanKelasMenengahDongkrakEkonomi.http://www.apindo.or.id/ index.php/berita-a-artikel/news/927-pertumbuhan-kelas-menengah-dongkrak-ekonomi. Retreaved on 2 May 2013.

Akbar, S. et.al 2012.Pendidikan KarakterMelaluiPendekatanMenyeluruh. Malang: FIP UM.

Aviliani, 2011.Demographic Bonus Dan PertumbuhanKelasMenengah. http://www. I apindo.or.id/ index.php/ berita-a-artikel/news/927. Accessed on 2 May 2013.

Biro PusatStatistik. 2010. Hasil Sensus Penduduk 2010. Jakarta: BPS

Bank Indonesia.2011. Analisis Sensitivitas Konsumsi Rumah Tangga terhadap PDB Dan Pengaruh Inflasi terhadap Pola Konsumsi. Jakarta: Bank Indonesia.

Bank Indonesia.2011. Informasi Kependudukan Indonesia. Jakarta: Bank Indonesia.

Borg, W. R. \& Gall, M.D. 1992.Educational Research. London: Longman 
Journal of Social Sciences (COES\&RJ-JSS), 6(1), pp. 1-13

Ciri-cirimanusia Indonesia Seutuhnya.[online]. http://id.answers.yahoo.com/ question/index.Accessed on : 20 February 2012

Creswell, JW. 2002 Research Design Qualitative, Quantitative, and Mixed Methodes Approach. California: Sage Publication.

Dick W. and Carey, 1996.Rancangan Sistem Pengajaran. TerjemahanMunandir. Jakarta: P2LPTK

Gorton, R.A and Schenelder, G.T. 1991.School Based Leadership. New York: Macmillan.

Gunadi, P. 2013. MengubahKompetitifMenjadiProdukti. Jakarta:

Imron, A., 1995. Kaitan Antara Manajemen Berbasis Sekolah dengan Mutu Pendidikan di SMP se Kabupaten Nganjuk, Kerja sama antara Puslitdik Lemlit UM dengan Balitbangda Kabupaten Nganjuk

Imron, A. 1997.Studi Identifikasi Masalah dan Alternatif Manajerial Manajemen Peserta Didik di Sekolah.LaporanPenelitian. Malang: Lemlit IKIP Malang.

Imron, A. 1998. Manajemen Peserta Didik di Sekolah: Kajian Masalah dan Alternatif Pemecahan Manajerialnya.Jurnal Ilmu Pendidikan. Malang: IKIP dan STKIP se Indonesia.

Imron, A. 2004.Kaitan Antara Implementasi Manajemen Berbasis Sekolah dengan Mutu Pendidikan di SMP se KabupatenNganjuk. LaporanPenelitian. Malang: Lemlit IKIP Malang.

Imron, A. 2005. Kajian Manajemen Pendidikan Sekolah Unggulan pada Satuan Pendidikan Sekolah Dasar, Jakarta: Ditjen Dikdasmen, Depdiknas.

Imron, A. 2009.Hubungan Kausal antara Implementasi Manajemen Berbasis Sekolah dengan

Prestasi Akademik dan Non Akademik di SMP se JawaTimur.LaporanPenelitian. Malang:

Lemlit UM.

Imron, A., et.al. 2011. PanduanPendidikanKarakterMelaluiKegiatanEkstraKurikuler. Jakarta:

Direktorat PembinaanSekolahDasar, Kemendikbud.

Imron, A. 2009.ManajemenMutu SD BerbasisReligi: Studi Multi Kasus pada SD Mintu, SD Iwaha, SD Kasayugadan SD Kripe. Malang: PPS UM.

Imron, A. 2010.Akarsosial, kulturaldanreligimanajemenmutu SD berbasisreligi. Jurnal IlmuPendidikanJilid 16, Nomor 3, Oktober 2009, hal.143-151. 
Imron, A. 2010. Profil manajemen sekolah unggulan pada satuan pendidikan sekolah dasar.

Jurnal Manajemen Pendidikan, Vol.1, No.1 Agustus, 2010: 1-14.

Imron, A. 2011.Peranankepala SMP dalamImplementasi MBS.

BerkalaManajemenPendidikan, Vol. 23, Nomor 4: 357-364.

Imron, A. 2011. Manajemen Peserta Didik Berbasis Sekolah. Jakarta: Bumi Aksara. Indrakusuma, A.D. 1990. Administrasi Kepegawaian. Malang: Jurusan AP FIP IKIP Malang.

Joice, B. dan Weil, B. 1980.Models of Teaching. New Jersey: Prentice-Hall, Inc.

KarakterManusiaSeutuhnya. [onlin). Accessed in: 20 February 2012

Kemendiknas, 2010.Kebijakan Nasional Pembangunan KarakterBangsa. Jakarta:

Kemendiknas.

Knezevich, S.J. 1981. Administration of Public Education. New York: Macmillan, Inc.

Lickona. 1992. Educating for Character: How our school can teach respect

\&responsibility. New York: Macmillan.

Mayring, P. 2000. Qualitative Content Analysis.Qualitative Social Research (OnlineJournal), 1 (2).

Morse, J.M. 1991. Approaches To Qualitative-Quantitative Methodological Triangulation. California: Sage Pub. Inc.

Puskur, Kemendikbud, 2009. PengembangandanPendidikanBudaya\&KarakterBangsa: PedomanSekolah. Jakarta: Puskur, Kemendiknas.

Sahertan, I.A dan Imron, A. 1996. Hubungan antara Tingkat Keterlibatan Orang Tua dalam Mendidik Anak Kaitannya dengan Motivasi dan Prestasi Belajar SD SD se Kacamatan Lowok Waru Kodya Malang. Laporan Penelitian Tidak Diterbitkan. Malang: Lembaga Penelitian IKIP Malang.

Steckler et al. 1992.Toward Integrating qualitative and quantitative methods: An Introduction. California: Sage Pub.Inc.

Stoops, E. and Johnson, T. 1985. Handbook of Educational Administration: A Guide for The Practitioner. Second Edition. Boston: Allyn and Bacon, Inc.

Tashakkori, A. Dan Teddelie, C. 2003.Hand Book of Mixed Methods in Behavioural Research. California: Sage Pub. Inc.

Yeager, William A.1985. Administration and The Pupil. New York: Harper and Brother. - Xxxxxxxxxxxxxxx 